\title{
PENGARUH CAR, NPF DAN BOPO TERHADAP ROA PADA BUS YANG TERDAFTAR DI BI
}

\author{
Lailatul Husna \\ Sekolah Tinggi Agama Islam Rokan Bagan Batu \\ E-mail: lailatulhusna128@gmail.com
}

\begin{abstract}
ABSTRAK
Penelitian ini bertujuan untuk menganalisis pengaruh Capital Adequacy Ratio (CAR), Non Performing Financing (NPF) dan Biaya Operasional Perpendapatan Operasional (BOPO) terhadap Return On Asset (ROA). Teknik analisis data pada penelitian ini menggunakan analisis regresi data panel. ROA sebagai variabel dependen, sedangkan CAR, NPF dan BOPO sebagai variabel independen. Pengolahan data menggunakan EViews 6. Penelitian ini memberikan hasil bahwa secara bersama-sama variabel dependen yaitu Return On Asset (ROA) dapat dijelaskan oleh variabel independen yang terdiri dari CAR, NPF dan BOPO berpengaruh signifikan terhadap ROA dengan nilai $R$ Square sebesar $89,4296 \%$ sedangkan sisanya sebesar 10,5704\% yang dijelaskan oleh variabel lain diluar penelitian ini. Variabel CAR dan NPF secara parsial memiliki pengaruh yang signifikan positif terhadap ROA, sedangkan variabel BOPO berpengaruh signifikan negatif terhadap ROA.
\end{abstract}

Kata Kunci : Capital Adequacy Ratio (CAR); Non Performing Financing (NPF); Biaya Operasional Perpendapatan Operasional (BOPO); Return On Asset (ROA).

\section{PENDAHULUAN}

untuk Bank syariah didirikan dengan tujuan untuk mempromosikan dan mengembangkan prinsip-prinsip Islam kedalam transaksi keuangan dan perbankan. Di Indonesia, bank syariah yang pertama didirikan pada tahun 1992 adalah Bank Muamalat Indonesia (BMI). Walaupun perkembangannya agak terlambat bila dibandingkan dengan negara-negara Muslim lainnya, perbankan syariah di Indonesia akan terus berkembang (Adiwarman A. Karim, 2010).

Berdasarkan Undang-Undang Perbankan Syariah Indonesia No. 21 Tahun 2008, disebutkan bahwa bank terdiri atas dua jenis yaitu bank konvensional dan bank syariah. Bank konvensional adalah bank yang menjalankan kegiatan usahanya secara konvensional yang terdiri atas Bank Umum Konvensional dan Bank Perkreditan Rakyat. Adapun bank syariah adalah bank yang menjalankan kegiatan usahanya berdasarkan prinsip syariah yang terdiri atas Bank Umum
Syariah (BUS) dan Bank Pembiayaan Rakyat Syariah (BPRS). Bank Umum Syariah yang kegiatannya memberikan jasa dalam lalu lintas pembayaran. Sementara itu, BPRS adalah bank syariah yang melaksanakan kegiatan usahanya tidak memberikan jasa lalu lintas dalam pembayaran. Berdasarkan UU Perbankan Syariah No. 21 Tahun 2008 tersebut, disebutkan bahwa bank konvensional yang hendak melaksanakan usaha syariah harus membentuk Unit Usaha Syariah (UUS) yang khusus beroperasi menggunakan sistem syariah (Rizal Yaya, dkk, 2009).

Dalam UU No. 10 Tahun 1998 yang merupakan penyempurnaan UU No.7 Tahun 1992, secara tegas menentukan bahwa keegiatan-kegiatan usaha bank bagi hasil (baik bank umum dan bank perkreditan rakyat) harus memperhatikan prinsip kehatihatian (prudential principle) yang dalam operasionalnya dan rambu-rambu kesehatan bank (prudential standards), yang secara tegas menentukan bahwa bank wajib 
memelihara tingkat kesehatan bank sesuai dengan ketentuan kecukupan modal, kualitas aset, kualitas manajemen, likuiditas, rentabilitas, silvabilitas dan aset lain yang berhubungan dengan kegiatan usaha bank (Veithzal Rivai dan Arviyan Arifin, 2010).

Indikator yang biasa digunakan untuk mengukur tingkat profitabilitas suatu perusahaan adalah Return On Equity (ROE) untuk perusahaan pada umumnya dan Return On Assets (ROA) pada industri perbankan. Keduanya dapat digunakan dalam mengukurnya besarnya kinerja keuangan pada industri perbankan. Namun umumnya, ROE hanya mengukur return yang diperoleh dari investasi dari pemilik perusahaan, sedangkan ROA lebih memfokuskan kemampuan perusahaan untuk memperoleh earning dalam operasi perusahaan (Dahlan Siamat, 2007).

Alasan dipilihnya Return On Assets (ROA) sebagai ukuran kinerja dalam penilitian ini karena ROA merupakan metode pengukuran yang obyektif yang didasarkan pada data akuntansi yang tersedia dan besarnya ROA dapat mencerminkan hasil dari serangkaian kebijakan perusahaan terutama perbankan.

Selain itu faktor-faktor penentu profitabilitas dapat dilihat dari faktor internalnya yang meliputi kecukupan modal, efisiensi operasional, likuiditas dan ukuran asset. Karena dari faktor internal menggambarkan kondisi bank dan kinerja bank selama menjalankan aktifitasnya sebagai lembaga intermediasi. Gambaran mengenai kinerja bank dapat dilihat dari laporan keuangan yang bersangkutan. Dalam penelitian ini terdapat rasio-rasio yang dipergunakan untuk menilai tingkat kesehatan bank yaitu rasio CAR, NPF, BOPO dan ROA.

\section{Grafik I}

Grafik Persentase Return On Asset (ROA) Bank Umum Syariah

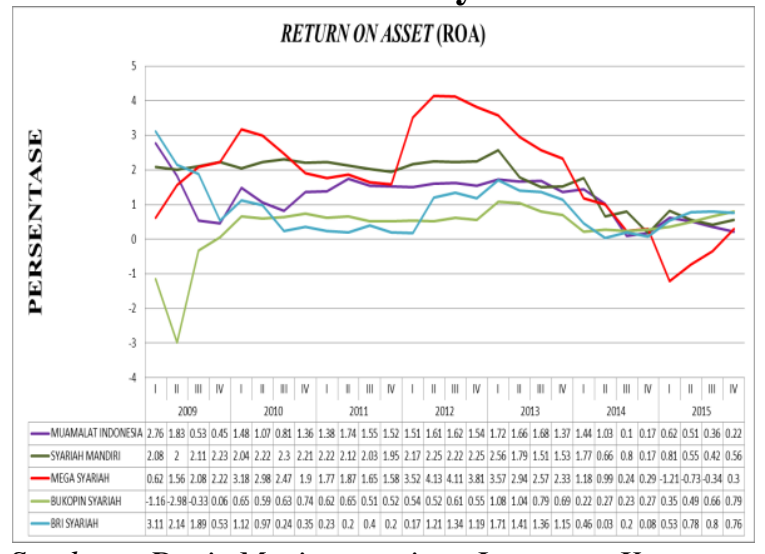

Sumber: Dari Masing-masing Laporan Keuangan BUS (Data Diolah Penulis).

Return On Asset (ROA) adalah rasio profitabilitas yang menunjukan perbandingan antara laba (sebelum pajak) dengan total aset bank, rasio ini menunjukkan tingkat efisiensi pengelolaan aset yang dilakukan oleh bank yang bersangkutan (Selamet Riyadi, 2006). Bank Muamalat Indonesia pada tahun 2009 mengalami penurunan tetapi pada tahun 2010 triwulan I mengalami kenaikan sebesar $1,03 \%$ dari $0,45 \%$ menjadi $1,48 \%$ tetapi kembali turun sampai triwulan ke III dan kembali naik pada triwulan ke IV. Pada tahun 2011 mengalami fluktuasi dan di tahun 2012 mengalami kenaikan hingga triwulan ke III tetapi turun kembali pada triwulan ke IV. Kemudian pada tahun 2013 pada triwulan I Bank Muamalat Indoensia mengalami kenaikan ROA sebesar $0,18 \%$ dari $1,54 \%$ menjadi $1,72 \%$ dan mengalami fluktuasi ROA hingga triwulan ke IV. Pada tahun 2014 triwulan I ROA kembali naik tetapi masih tidak stabil dan masih mengalami naik turunnya ROA hingga triwulan ke IV. Kemudian pada tahun 2015 ROA terus menerus mengalami penurunan hingga akhir tahun.

Berikutnya Bank Syariah Mandiri pada tahun 2009 mengalami penurunan ROA hingga triwulan ke II dan kembali naik 
sampai akhir tahun. Pada awal triwulan tahun 2010, ROA mengalami penurunan sebesar $0,19 \%$ dari $2,23 \%$ menjadi $2,04 \%$ dan kembali naik hingga triwulan ke III tetapi turun pada triwulan ke IV. Pada triwulan I tahun 2011 ROA kembali mengalami kenaikan hanya $0,01 \%$ tetapi mengalami penurunan hingga akhir tahun. Pada tahun 2012 ROA mengalami kenaikan hingga triwulan ke II dan kembali turun pada triwulan ke III tetapi pada triwulan ke IV ROA kembali naik sebesar $0,03 \%$ dari $2,22 \%$ menjadi 2,25\%. Pada tahun 2013 ROA mengalami fluktuasi hingga akhir tahun 2015.

Selanjutnya Bank Mega Syariah pada tahun 2009 mengalami kenaikan terus menerus hingga triwulan I tahun 2010, kemudian pada triwulan ke II mengalami penurunan hingga triwulan pertama tahun 2011. Pada triwulan II tahun 2011 ROA kembali naik sebesar $0,10 \%$ dari $1,77 \%$ menjadi $1,87 \%$ dan kembali turun hingga akhir tahun. Pada tahun 2012 triwulan I ROA kembali naik sampai triwulan II tetapi kembali turun hingga tahun 2014 triwulan III tetapi pada triwulan ke IV ROA naik kembali $0,05 \%$ dari $0,24 \%$ menjadi $0,29 \%$. Pada awal triwulan tahun 2015 ROA kembali turun bahkan mencapai angka minus (-) yaitu $-1,21 \%$, akan tetapi pada triwulan ke II hingga triwulan ke IV ROA mengalami kenaikan dan keluar dari wilayah minus (-) menjadi 0,30\%.

Kemudian Bank Bukopin Syariah pada tahun 2009 triwulan I sampai triwulan III ROA mengalami minus (-), berhasil keluar serta mengalami peningkatan dari $0,33 \%$ menjadi $0,06 \%$ pada triwulan ke IV dan terus meningkat hingga tahun 2010 triwulan I sebesar $0,59 \%$ menjadi $0,65 \%$. Tetapi kembali turun pada triwulan II menjadi $0,59 \%$ dan pada triwulan III hingga triwulan IV mengalami peningkatan. Persentase ROA pun kembali mengalami fluktuasi pada tahun 2011 hingga akhir tahun 2012. Pada tahun 2013 triwulan I ROA mengalami kenaikan sebesar $0,53 \%$ dari $0,55 \%$ menjadi $1,08 \%$ tetapi terus mengalami penurunan hingga tahun 2014 triwulan I. Pada triwulan II hingga triwulan IV tahun 2014 ROA mengalami fluktuasi. Pada tahun 2015 triwulan I sampai triwulan IV ROA terus mengalami kenaikan hingga $0,44 \%$ dari $0,27 \%$ menjadi $0,79 \%$.

Terakhir Bank BRI Syariah pada tahun 2009 mengalami penurunan ROA. Pada awal triwulan tahun 2010, ROA naik dari $0,53 \%$ menjadi $1,12 \%$ tetapi mengalami penurunan kembali sampai akhir tahun. Pada tahun 2011 ROA masih mengalami penurunan, hingga pada triwulan ke III ROA naik dari $0,20 \%$ menjadi $0,40 \%$, tetapi kembali turun pada akhir tahun. Pada tahun 2013 ROA mengalami fluktuasi. Pada tahun 2013 ROA kembali mengalami penurunan terus menerus hingga tahun 2014 triwulan II dan ROA mengalami kenaikan pada triwulan III tetapi kembali turun pada akhir tahun. Pada tahun 2015 ROA kembali mengalami kenaikan, tetapi masih juga turun pada akhir tahun. Setiap bank memiliki persentase rasio ROA yang berbeda-beda dan itu dapat kita lihat melalui data pada grafik 1.1 di atas.

\section{METODE}

Adapun tujuan penelitian yang akan diperoleh dalam penelitian ini diantaranya untuk mengetahui apakah CAR, NPF dan BOPO berpengaruh terhadap ROA pada BUS yang terdaftar di BI baik itu secara parsial maupun simultan. Metode penelitian yang digunakan dalam penelitian ini adalah metode penelitian normatif, pada umumnya metode pengumpulan data yang digunakan adalah model literature dengan mengumpulkan berbagai referensi yang berhubungan dengan masalah penelitian. Penelitian ini adalah penelitian pustaka (library research) yang datanya merupakan data laporan keuangan BUS (Bank Umum 
Syariah) yang ada di situs resmi Bank Indonesia.

Jenis data yang digunakan dalam penelitian ini adalah data sekunder. Data sekunder adalah data yang diperoleh lewat pihak lain tidak langsung diperoleh oleh peneliti dari subjek penelitiannya. Data sekunder biasanya berwujud data dokumentasi atau data laporan yang telah tersedia (Etta Mamang Sangadji, 2010). Data sekunder yang digunakan dalam penelitian ini adalah berupa data rasio-rasio yang terdapat dalam laporan keuangan seperti rasio CAR, rasio NPF, rasio BOPO dan rasio ROA.

Metode pengumpulan data dalam penilitian ini menggunakan studi dokumentasi yaitu pengumpulan data yang tidak langsung ditujukan pada subyek penelitian, namum melalui dokumen. Dokumen yang digunakan dapat berupa buku harian, surat pribadi, laporan, notulen rapat, catatan kasus dalam pekerjaan sosial dan dokumen lainnya. Dalam penelitian ini metode pengumpulan data yang dilakukan adalah dengan metode file research yang di peroleh dari situs resmi laporan keuangan BI (Bank Indonesia), (2016), OJK (Otoritas Jasa Keuangan) ( 2016), Bank Muamalat Indonesia (2016), Bank Syariah Mandiri (2016), Bank Mega Syariah (2016), Bank Bukopin Syariah (2016) dan Bank Rakyat Indonesia (2016).

Dalam penelitian ini metode analisis yang digunakan adalah analisis regresi data panel. Data panel adalah data yang berstruktur urut waktu sekaligus cross section. Data semacam ini dapat diperoleh misalnya dengan mengamati serangkaian observasi cross section (antarindividu) pada suatu periode tertentu (Moch. Doddy Ariefianto, 2012).

Uji regresi panel ini digunakan untuk mengetahui hubungan antara variabel independen (bebas) yang terdiri dari Capital Adequacy Ratio, Non Performing Financing dan Biaya Operasional Perpendapatan Operasional. Untuk membantu penelitian, peneliti akan menggunakan Software Microsoft Excel dan pengolahan data statistik EViews 9.0

Model regresi panel dalam penelitian ini adalah:

$$
Y_{i t}=c+b_{1} X_{1 i t}+b_{2} X_{2 i t}+b_{3} X_{3 i t}+e_{i t}
$$

Keterangan:

$\mathrm{Y}=$ Fraud

$\mathrm{C}=$ Konstanta

$\mathrm{X}_{1}=$ Capital Adequacy Ratio

$\mathrm{X}_{2}=$ Non Performing Financing

$\mathrm{X}_{3}=$ Biaya Operasional Perpendapatan perasional

Estimasi Model Data Panel

Metode estimasi model regresi dengan menggunakan data panel dapat dilakukan melalui tiga pendekatan antara lain (Jonni J Manurung, dkk, 2010):

a. Metode Common Effect atau Pooled Least Square (PLS)

Pooled Least Square Model

merupakan metode estimasi model regresi data panel yang paling sederhana dengan asumsi intercept dan koefisien slope yang konstan antar waktu dan cross section (common effect). Dalam pendekatan ini tidak memperhatikan dimensi individu maupun waktu. Diasumsikan bahwa perilaku data antar perusahaan sama dalam berbagai kurun waktu.

Bentuk untuk model Ordinary Least Square adalah:

$$
Y_{i t}=b_{0}+b_{1} X_{1 i t}+b_{2} X_{2 i t}+b_{3} X_{3 i t}+\varepsilon_{i t}
$$

dimana $\mathrm{i}=1,2,3,4,5$ dan $\mathrm{t}=1,2, \ldots, 28$. $\mathrm{Y}_{\mathrm{it}}=$ variabel dependen untuk individu ke-i dan waktu ke-t

$\mathrm{X}_{\mathrm{it}}=$ variabel independen untuk individu ke-i dan waktu ke-t

b. Metode Fixed Effect Model (FEM)

Teknik model Fixed Effect adalah teknik mengestimasi data panel dengan menggunakan variabel dummy unuk menangkap adanya perbedaan intersep. Model fixed effect juga disebut 
covariance model dan variabel independentnya disebut covariate.

Persamaan pada estimasi dengan menggunakan Fixed Effect Model dapat ditulis dalam bentuk sebagai berikut:

$$
Y_{i t}=\alpha_{1}+\alpha_{2} D_{2 i}+\alpha_{3} D_{3 i}+\alpha_{4} D_{4 i}+\alpha_{5} D_{5 i}+
$$

Keterangan:

$\mathrm{Y}_{\text {it }}=$ Return On Asset (ROA)

$\mathrm{X}_{\text {it }}=$ Variabel Independen (CAR, NPF dan BOPO)

$\mathrm{D}_{2 \mathrm{i}}=$ Dummy 1, jika perusahaan tersebut BSM 0, jika lainnya

$\mathrm{D}_{3 \mathrm{i}}=$ Dummy 1, jika perusahaan tersebut BMS 0, jika lainnya

$\mathrm{D}_{4 \mathrm{i}}=$ Dummy 1, jika perusahaan tersebut BBS 0, jika lainnya

$\mathrm{D}_{5 \mathrm{i}}=$ Dummy 1, jika perusahaan tersebut BRIS 0, jika lainnya

Dalam hal ini, perusahaan yang diasumsikan sebagai perusahaan control adalah BMI sehingga nilai $\alpha_{1}$ adalah koefisien milik BMI.

\section{c. Metode Random Effect Model (REM)}

Penggunaan model random effect relatif mahal terhadap derajat bebas jika data cross-section terbatas. Pengetahuan yang terbatas terhadap makna variabel boneka (dummy) mendorong penggunaan Error Component Model (ECM) atau Random Effects Model (REM).

Menurut Agus Widarjono, model random effect ini menggunakan variabel gangguan (error terms). Model ini mengestimasi data panel dimana variabel gangguan mungkin saling berhubungan antar waktu dan antar individu (Agus Widarjono, 2013).

Model random effect dapat di formulasikan sebagai berikut:

\begin{tabular}{ll}
\hline & $Y_{i t}=\alpha+b X_{i t}+\varepsilon_{i t} ; \varepsilon_{i t}=U_{i}+V_{t}+W_{i t}$ \\
Dimana: & \\
$\mathrm{U}_{\mathrm{i}}=$ & Komponen Error Cross-Section \\
$\mathrm{V}_{\mathrm{t}}=$ & Komponen Error Time-Series
\end{tabular}

$\mathrm{W}_{\mathrm{it}}=\quad$ Komponen Error Gabungan Untuk memilih model mana yang paling tepat digunakan untuk pengolahan data panel, maka terdapat beberapa pengujian yang dapat dilakukan, antara lain: a. Uji Chow

Uji Chow adalah teknik uji yang digunakan untuk membandingkan apakah model yang digunakan Pooled Least Square Model atau Fixed Effect Model. Uji ini juga untuk menguji stabilitas parameter jika data yang digunakan adalah data uraian waktu (Prapto Yuwono, 2005). Dalam pengujian ini dilakukan dengan hipotesis sebagai berikut:

$\mathrm{H}_{0}=$ Pooled Least Square Model (PLSM)

$\mathrm{H}_{\mathrm{a}}=$ Fixed Effect Model (FEM)

Dasar penolakan terhadap hipotesis di atas adalah dengan membandingkan perhitungan $F_{\text {statistik dengan }} F_{\text {tabel }}$. Perbandingan dipakai apabila $F_{\text {hitung }}$ lebih besar (>) dari $\mathrm{F}_{\text {tabel, }}$ maka $\mathrm{H}_{0}$ ditolak yang berarti model yang lebih tepat digunakan adalah Fixed Effect Model. Begitupun sebaliknya, jika $F_{\text {hitung }}$ lebih kecil $(<)$ dari

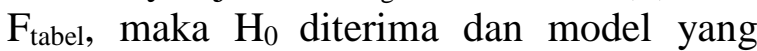
lebih tepat digunakan adalah Common Effect Model (Gujarati, N. Damodor dan Dawn C Porter, 2009).

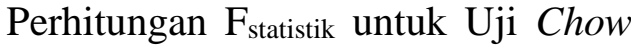
dapat dilakukan dengan rumus:

$$
\mathrm{F}_{0}=\frac{\frac{(\text { RRSS }- \text { URSS })}{(N-1)}}{\frac{U R S S}{(N T-N-K)}}
$$

Keterangan:

RRSS = Restricted Residual Sum Square (merupakan Sum of Square Residual yang diperoleh dari estimasi data panel dengan model Pool Least Squarel Common Effect (Common Intercept).

URSS = Unrestricted Residual Sum Square (merupakan Sum of Square Residual yang diperoleh dari estimasi data panel dengan metode Fixed Effect 


$$
\begin{aligned}
& \mathrm{N}=\text { Jumlah Data Cross Section } \\
& \mathrm{T}=\text { Jumlah Data Time Series } \\
& \mathrm{K}=\text { Jumlah Variabel (Bebas dan Terikat) } \\
& \text { Sedangkan F } F_{\text {tabel }} \text { didapat dari: } \\
& \quad F_{\text {tabel }}=\{\alpha: d f(N-1),(N T-N-K)\}
\end{aligned}
$$

\section{b. Uji Hausman}

Hausman test adalah pengujian statistik untuk memilih apakah model fixed effect atau random effect lebih tepat digunakan dalam regresi data panel. Uji ini bertujuan untuk melihat apakah terdapat efek random di dalam panel data (Dedi Rosadi, 2012). Pengujian dilakukan dengan hipotesis berikut:

\section{$\mathrm{H}_{0}:$ Random Effect Model}

$\mathrm{H}_{1}$ : Fixed Effect Model

Jika chi-square hitung > chisquare tabel berarti $\mathrm{H}_{0}$ ditolak, artinya model yang digunakan adalah fixed effect model. Jika chi-square hitung < chi-square tabel berarti $\mathrm{H}_{1}$ ditolak, artinya model yang digunakan adalah random effect model (Gujarati, N. Damodor dan Dawn C Porter, 2009).

\section{Uji Signifikansi}

a. Uji Parsial (Uji Statistik t)

Uji statistik $t$ pada dasarnya menunjukkan seberapa jauh pengaruh satu variabel penjelas/ independen secara individual dalam menerangkan variasi variabel dependen. Hipotesis nol $\left(\mathrm{H}_{0}\right)$ yang hendak di uji adalah apakah suatu parameter (bi) sama dengan nol, atau $\mathrm{H}_{0}$ : bi $=0$.

Artinya, variabel tersebut merupakan penjelas yang signifikan terhadap variabel dependen. Cara melakukan uji t adalah sebagai berikut:

1) Quick Look, bila jumlah degree of freedom (df) adalah 20 atau lebih dan derajat kepercayaan sebesar 5\%, maka $\mathrm{H}_{0}$ yang menyatakan $\mathrm{b}_{\mathrm{i}}=0$ dapat ditolak bila nilai t lebih besar dari 2 (dalam nilai absolut). Dengan kata lain kita menerima hipotesis alternatif yang menyatakan bahwa suatu variabel independen secara individual mempengaruhi variabel dependen.

2) Membandingkan nilai statistik $t$ dengan titik kritis menurut tabel. Apabila nila statistik $\mathrm{t}$ hasil perhitungan lebih tinggi dibandingkan nilai $t_{\text {tabel}}$, kita menerima hipotesis alternatif yang menyatakan bahwa suatu variabel independen secara individual mempengaruhi variabel dependen.

Adapun nilai probabilitas dalam penelitian ini diperoleh dengan membagi dua nilai probabilitas yang muncul dalam output persamaan regresi. Hal ini dilakukan karena dalam penelitian ini, uji yang digunakan adalah uji satu arah sedangkan nilai probablitas untuk uji dua arah, sehingga nilai probabbilitas harus dibagi dua (Agus Widarjono, 2013). Uji ini dilakukan dengan membandingkan thitung dengan $t$ tabel. Adapun nilai tabel diperoleh dengan df : $\alpha$ (N-K) dimana $\alpha$ adalah tingkat signifikansi yang digunakan, $\mathrm{N}$ adalah jumlah pengamatan (ukuran sampel), dan $\mathrm{K}$ adalah jumlah variabel independep dan dependen. Dasar pengambilan keputusannya adalah jika thitung $>\mathrm{t}_{\text {tabel}}$, berarti $\mathrm{H}_{0}$ ditolak yang berarti bahwa variabel $\mathrm{X}_{\mathrm{i}}$ berpengaruh signifikan terhadap variabel dependen, tetapi jika thitung $<\mathrm{t}_{\text {tabel}}$, maka $\mathrm{H}_{0}$ diterima yang berarti bahwa variabel $X_{\mathrm{i}}$ tidak berpengaruh signifikan terhadap variabel dependen.

b. Uji Signifikansi Simultan (Uji Statistik F)

Untuk menyimpulkan apakah model masuk dalam kategori cocok (fit) atau tidak, kita harus membandingkan nilai $F_{\text {hitung }}$ dengan nilai $F_{\text {tabel }}$ dengan derajat bebas: df: $\alpha,(\mathrm{k}-1),(\mathrm{n}, \mathrm{k})$, dimana $\mathrm{k}$ adalah jumlah variabel independen dan dependen dan $n$ adalah jumlah pengamatan (ukuran sampel). Dasar pengambilan keputusannya adalah jika nilai $\mathrm{F}_{\text {hitung }}>\mathrm{F}_{\text {tabel }}$, maka $\mathrm{H}_{0}$ ditolak dan $\mathrm{H}_{1}$ diterima yang berarti bahwa variabel independen secara simultan tidak berpengaruh terhadap variabel dependen.

Uji statistik $F$ pada dasarnya menunjukkan apakah variabel independen 
atau bebas yang dimasukkan dalam model mempunyai pengaruh yang secara bersamasama terhadap variabel dependen/ terikat. Hipotesis nol $\left(\mathrm{H}_{0}\right)$ yang hendak diuji adalah apakah semua parameter dalam model regresi sama dengan nol, atau:

$\mathrm{H}_{0}: \mathrm{b}_{1}, \mathrm{~b}_{2}, \mathrm{~b}_{3}=0$

$$
\text { Artinya, semua variabel }
$$

independen secara simultan merupakan penjelas yang signifikan terhadap variabel dependen. Untuk menguji hipotesis ini digunakan statistik $\mathrm{F}$ dengan kriteria pengambilan keputusan sebagai berikut:

1) Quik Look, bila nilai F lebih besar daripada 4 maka $\mathrm{H}_{0}$ dapat ditolak dengan derjat kepercayaan 5\%, dengan kata lain kita menerima hipotesis alternative, yang menyatakan semua variabel independen secara serentak dan signifikan mempengaruhi variabel dependen.

2) Membandingkan nilai $F$ hasil perhitungan dengan nilai $\mathrm{F}$ menurut tabel. Bila nilai $F_{\text {hitung }}$ lebih besar daripada nilai $\mathrm{F}_{\text {tabel, }}$, maka $\mathrm{H}_{0}$ ditolak dan menerima $\mathrm{H}_{\mathrm{a}}$.

c. Uji R ${ }^{2}$ (Koefisien Determinasi)

Koefisien Determinasi $\left(\mathrm{R}^{2}\right)$ adalah sebuah persentase yang menunjukkan persentase pengaruh semua variabel independen terhadap variabel dependen. Persentase tersebut menunjukkan seberapa besar variabel independen dapat menjelaskan variabel dependennya. Nilai $\mathrm{R}^{2}$ mempunyai interval $0-1\left(0<\mathrm{R}^{2}<1\right)$ semakin besar $\mathrm{R}^{2}$, semain baik hasil model regresi tersebut dan semakin mendekati 0, maka variabe independen secara keseluruhan dapat menjelaskan variabel dependennya (Wahid Sulaiman,2014).

\section{HIPOTESIS}

Menurut Juliansyah Noor Hipotesis sebagai hubungan yang diperkirakan secara logis di antara dua atau lebih variabel yang diungkap dalam bentuk pernyataan yang dapat diuji. Dalam rangkaian langkahlangkah penelitian yang disajikan dalam bab ini hipotesis itu merupakan rangkuman dari kesimpulan-kesimpulan teoretis yang diperoleh dari penelaahan kepustakaan. Hipotesis merupakan jawaban terhadap masalah penelitian yang secara teoretis dianggap paling mungkin dan paling tinggi tingkat kebenarannya (Sumadi Suryabrata, 2006).

Hipotesis penelitian dinyatakan sebagai berikut:

Hipotesis 1: Capital Adequacy Ratio (CAR) berpengaruh secara signifikan positif terhadap Return On Asset (ROA) Bank Umum Syariah.

Hipotesis 2: Non Performing Financing (NPF) berpengaruh secara signifikan negatif terhadap Return On Asset (ROA) Bank Umum Syariah.

Hipotesis 3: Biaya Operasional Perpendapatan Operasional (BOPO) berpengaruh secara signifikan negatif terhadap Return On Asset (ROA) Bank Umum Syariah.

Hipotesis 4: CAR, NPF dan BOPO berpengaruh secara signifikan dan simultan terhadap ROA Bank Umum.

\section{HASIL DAN PEMBAHASAN}

Return On Asset (ROA) digunakan untuk mengukur kemampuan bank dalam memperoleh keuntungan secara keseluruhan. Semakin besar ROA suatu bank, maka semakin besar pula tingkat keuntungan yang dicapai bank tersebut dan semakin baik pula posisi bank tersebut dari sisi penggunaan aset (Amir Machmud dan Rukmana,2009).

Menurut Nadia Harini Haq, ROA merupakan rasio yang digunakan untuk mengetahui kemampuan Bank dalam menghasilkan keuntungan dari pengelolaan 
aset yang dimiliki oleh bank. ROA sebagai salah satu ukuran profitabilitas dapat melihat pencapaian laba suatu Bank. Hal ini dikarenakan aset merupakan kekayaan Bank yang dananya berasal dari sebagian besar dana simpanan masyarakat. Efisiensi penggunan aset dalam menghasilkan laba dapat ditunjukkan dari semakin besarnya ROA yang dimiliki oleh perusahaan (Nadia Arini Haq, 2005).

Untuk menghitung ROA dapat digunakan rumus sebagai berikut:

$$
\text { ROA }=\frac{\text { Laba Sebelum Pajak }}{\text { Total Aktiva }} \times 100 \%
$$

Klasifikasi tingkat ROA menurut Bank Indonesia secara rinci adalah sebagai berikut:

\section{Tabel I}

Klasifikasi Tingkat ROA Menurut BI

\begin{tabular}{|c|c|}
\hline Tingkat ROA & Predikat \\
\hline Di atas $1,22 \%$ & Sehat \\
\hline $0,99 \%-1,22 \%$ & Cukup Sehat \\
\hline $0,77 \%-0,99 \%$ & Kurang Sehat \\
\hline Di bawah $0,77 \%$ & Tidak Sehat \\
\hline
\end{tabular}

Sumber:www.bi.go.id (Data Diolah Penulis)

Kecukupan modal merupakan faktor yang penting bagi bank dalam rangka pengembangan usaha dan menampung risiko kerugian karena dengan modal yang mencukupi, memungkinkan bagi manajemen bank yang bersangkutan untuk bekerja dengan efisiensi yang tinggi seperti yang dikehendaki oleh para pemilik modal bank tersebut (Arridho Yunanda,2013).

CAR atau biasa disebut dengan rasio kecukupan modal merupakan rasio yang menunjukkan kemampuan bank dalam mempertahankan modal yang mencukupi dan kemampuan manajemen bank dalam mengukur, mengidentifikasi, mengontrol dan mengawasi risiko-risiko yang timbul dan dapat mempengaruhi besarnya modal bank (Ridhlo Ilham Putra Wardana, 2015).

Berdasarkan peraturan Bank Indonesia Nomor 15/12/PBI/2013 tentang Kewajiban Penyediaan Modal Minimum Bank Umum Pasal 2 ayat 3 penyediaan modal minimum dibagi menjadi 4 kategori yaitu paling rendah $8 \%$ untuk dari ATMR untuk bank dengan profil risiko tingkat satu; paling rendah $9 \%$ sampai kurang 10\% dari ATMR untuk bank dengan profil risiko peringkat dua; paling rendah $10 \%$ sampai dengan kurang dari $11 \%$ dari ATMR untuk bank dengan profil risiko peringkat 3; atau $11 \%$ sampai dengan 14\% dari ATMR untuk bank dengan profil risiko peringkat 4 atau peringkat 5. Berdasarkan ketentuan Bank Indonesia yang tercantum dalam Surat Edaran Bank Indonesia Nomor 3/30/DPNP tanggal 14 Desember 2001, CAR adalah rasio antara Modal terhadap Aktiva Tertimbang Menurut Risiko (ATMR) dengan rumus :

$$
\text { CAR }=\frac{\text { Modal }}{\text { ATMR }} \times 100 \%
$$

Selain itu Capital Adequacy Ratio (CAR) ini digunakan untuk mengukur proporsi modal sendiri dibandingkan dengan dana dari luar di dalam pembiayaan kegiatan usaha perbankan. semakin besar rasio tersebut maka semakin baik posisi modal bank (Veithzal Rivai, 2007).

Klasifikasi tingkat CAR menurut Bank Indonesia secara rinci adalah sebagai berikut:

\section{Tabel II}

Klasifikasi Tingkat CAR Menurut BI

\begin{tabular}{|c|c|}
\hline Tingkat CAR & Predikat \\
\hline $8 \%$ ke atas & Sehat \\
\hline $6,4 \%-7,9 \%$ & Kurang Sehat \\
\hline Di bawah 6,4\% & Tidak Sehat \\
\hline $\begin{array}{l}\text { Sumber: www.bi.go.id } \\
\text { Penulis) } \\
\text { Non Performing Dinancing (NPF) }\end{array}$ \\
\hline
\end{tabular}
yang analog dengan Non Performing Loan (NPL) pada bank konvensional merupakan rasio keuangan yang berkaitan dengan risiko kredit. Non Performing Financing menunukkan kemampuan manajemen bank dalam mengelola pembiayaan bermasalah yang diberikan oleh bank. Sehingga semakin tinggi rasio ini maka akan semakin buruk kualitas kredit bank yang menyebabkan 
jumlah kredit bermasalah semakin besar, kemungkinan suatu bank dalam kondisi bermasalah semakin besar. Kredit dalam hal ini adalah kredit yang diberikan kepada pihak ketiga tidak termasuk kredit kepada bank lain.

NPF (Non Performing Financing) atau pembiayaan bermasalah berarti pembiayaan yang pelaksanaannya belum mencapai atau memenuhi target yang diinginkan pihak bank, seperti:

a. Pengembalian pokok atau bagi hasil yang bermasalah.

b. Pembiayaan yang memiliki timbulnya risiko dikemudian hari bagi bank.

c. Pembiayaan yang termasuk dalam golongan khusus, diragukan dan macet.

d. Golongan lancar yang berpotensi terjadi penunggakan dalam pengembalian.

Besarnya nilai NPF suatu bank dapat dihitung dengan rumus:

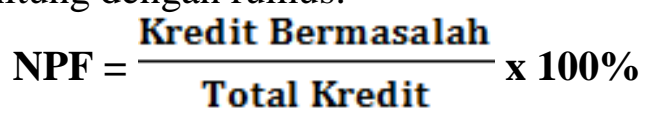

NPF merupakan rasio penunjang dalam menentukan kualitas aset bank syariah. Penilaian kualitas aset dimaksudkan untuk menilai kondisi aset bank, termasuk antisipasi atas risiko gagal bayar dari pembiayaan (credit risk) yang akan muncul.

Klasifikasi tingkat NPF menurut Bank Indonesia secara rinci adalah sebagai berikut:

\section{Tabel III}

\section{Klasifikasi Tingkat NPF Menurut BI}

\begin{tabular}{|c|c|c|}
\hline Peringkat & Nilai NPF & Predikat \\
\hline 1 & $\mathrm{NPF}<2 \%$ & Sangat Baik \\
\hline 2 & $2 \% \leq \mathrm{NPF}<5 \%$ & Baik \\
\hline 3 & $5 \% \leq \mathrm{NPF}<8 \%$ & Cukup Baik \\
\hline 4 & $8 \% \leq \mathrm{NPF}<12 \%$ & Kurang Baik \\
\hline 5 & $\mathrm{NPF} \geq 12 \%$ & Tidak Baik \\
\hline \multicolumn{3}{|c|}{ Sumber: $S E$ BI No.9/24/Dpbs Tgl 30 Oktober 2007 } \\
BOPO adalah perbandingan antara \\
biaya operasional dengan pendapatan \\
operasional. BOPO digunakan untuk \\
mengukur tingkat efisiensi dan kemampuan
\end{tabular}

bank dalam melakukan kegiatan operasionalnya. BOPO dapat dihitung dengan rumus sebagai berikut:

$$
\text { BOPO }=\frac{\text { Biaya 0perasional }}{\text { Pendapatan 0perasional }} \times 100 \%
$$

Menurut Lukman pada skripsi Daris Purba yang termasuk beban operasional adalah semua jenis biaya yang berkaitan langsung dengan kegiatan usaha bank. Beban operasional terdapat dalam laporan laba rugi yang diperoleh dengan menjumlahkan biaya bagi hasil, biaya tenaga kerja, biaya umum administrasi, biaya penyusutan dan penyisihan aktiva produktif, biaya sewa gedung dan inventaris dan sebagainya (Daris Purba, 2011).

Berdasarkan tabel klasifikasi tingkat BOPO, semakin kecil rasio ini berarti semakin efisien biaya operasional yang dikeluarkan bank yang bersangkutan sehingga kemungkinan suatu bank dalam kondisi bermasalah dan semakin kecil rasio ini maka kinerja bank semakin baik. Dengan demikian efisiensi operasi suatu bank yang diproksikan dengan rasio BOPO akan mempengaruhi kinerja bank tersebut.

Ketentuan tingkat BOPO menurut Peraturan Bank Indonesia (PBI) No.14/18/PBI/2012 adalah sebagai berikut:

\section{Tabel IV}

Klasifikasi Tingkat BOPO Menurut BI

\begin{tabular}{|c|c|}
\hline Tingkat BOPO & Predikat \\
\hline Di bawah $93,52 \%$ & Sehat \\
\hline $93,52 \%-94,72 \%$ & Cukup Sehat \\
\hline $94,72 \%-95,92 \%$ & Kurang Sehat \\
\hline Di atas 95,92\% & Tidak Sehat \\
\hline
\end{tabular}

Sumber: www.bi.go.id (Data Diolah Penulis) 


\section{Uji Chow}

\begin{tabular}{|c|c|c|c|c|}
\hline \multicolumn{5}{|c|}{$\begin{array}{l}\text { Hasil Uji Metod } \\
\text { Redundant Fixed Effects Tests } \\
\text { Pool: ANGUIH } \\
\text { Test cross-section fixed effects }\end{array}$} \\
\hline \multicolumn{2}{|l|}{ Effects Test } & Statistic & d.f. & Prob. \\
\hline \multicolumn{2}{|l|}{ Cross-section F } & \multicolumn{2}{|c|}{$34.277314(4,132)$} & 0.0000 \\
\hline \multicolumn{2}{|c|}{ Cross-section Chi-square } & \multicolumn{2}{|c|}{99.7241744} & \\
\hline $\begin{array}{l}\text { Cross-section fixed e } \\
\text { Dependent Variable: } \\
\text { Method: Panel Least } \\
\text { Date: 08/18/16 Tim } \\
\text { Sample: 2009Q1 } 201 \\
\text { Included observation } \\
\text { Cross-sections incluc } \\
\text { Total pool (balanced }\end{array}$ & $\begin{array}{l}\text { ffects test ec } \\
\text { ROA? } \\
\text { Squares } \\
\text { e: } 11: 28 \\
5 Q 4 \\
\text { s: } 28 \\
\text { ed: } 5 \\
\text { observatior }\end{array}$ & quation: & & \\
\hline Variable & Coefficient & t Std. Error & t-Statistic & Prob. \\
\hline C & 9.844110 & 0.398998 & 24.67205 & 0.0000 \\
\hline CAR? & 0.023595 & 0.009590 & 2.460221 & 0.0151 \\
\hline NPF? & -0.030433 & 0.031213 & -0.974995 & 0.3313 \\
\hline BOPO? & -0.099242 & 0.004598 & -21.58554 & 0.0000 \\
\hline R-squared & 0.784501 & Mean d & ependent var & 1.192214 \\
\hline Adjusted R-squared & 0.779748 & S.D. dep & endent var & 1.051214 \\
\hline S.E. of regression & 0.493346 & Akaike i & nfo criterion & 1.452944 \\
\hline Sum squared resid & 33.10109 & Schwarz & criterion & 1.536991 \\
\hline Log likelihood & -97.70605 & Hannan & Quinn criter. & 1.487098 \\
\hline F-statistic & 165.0314 & Durbin-1 & Natson stat & 0.289788 \\
\hline Prob(F-statistic) & 0.000000 & & & \\
\hline
\end{tabular}

Sumber: Data Diolah Penulis

Hasil output di atas menunjukkan nilai Prob $=0,0000$ untuk Cross Section $F$ yang berarti nilainya kurang dari 0,05 . Sehingga dapat disimpulkan model fixed effect lebih tepat digunakan daripada model common effect.

Uji Chow juga dapat dilakukan dengan membandingkan perbandingan $F_{\text {statistik }}$ dengan $\mathrm{F}_{\text {tabel }}$ dengan pengambilan keputusan sebagai berikut:

a. Nilai $F_{\text {hitung }}>F_{\text {tabel, }}$ maka $\mathrm{H}_{0}$ ditolak dan $\mathrm{H}_{\mathrm{a}}$ diterima. b. Nilai $\mathrm{F}_{\text {hitung }}<\mathrm{F}_{\text {tabel, }}$, maka $\mathrm{H}_{0}$ diterima dan $\mathrm{H}_{\mathrm{a}}$ ditolak.

$$
\begin{aligned}
& \mathrm{F}=\frac{\frac{(33,10109-16,23632)}{(5-1)}}{\frac{16,23632}{(5 \times 28-5-4)}}=\frac{4,2161925}{\frac{16,23632}{139}} \\
& =\frac{4,2161925}{\frac{16,23632}{139}}=\frac{4,2161925}{0,11680805755396}= \\
& \begin{aligned}
& 36,095 \\
& F_{\text {tabel }} \mathrm{df}=\alpha,(\mathrm{N}-1),(\mathrm{N} . \mathrm{T}-\mathrm{N}-\mathrm{K}) \\
&=0.05,(5-1),(5 \times 28-5-4) \\
&=0.05,(4),(139)=2,44
\end{aligned}
\end{aligned}
$$


Diperoleh $\mathrm{F}_{\text {statistik }}$ untuk uji Chow adalah 36,095 dengan $F_{\text {tabel }}$ df: $\alpha,(\mathrm{N}-1)$, (NT-N-K) atau 0.05, (5-1), (5x28-5-4) adalah 2,44 yang berarti $F_{\text {hitung }}>F_{\text {tabel, }}$, maka
$\mathrm{H}_{0}$ ditolak dan $\mathrm{H}_{\mathrm{a}}$ diterima. Sehingga dapat disimpulkan model Fixed Effect lebih tepat digunakan daripada model Common Effect.

\section{Uji Hausman}

\section{Tabel VI}

\section{Hasil Uji Hausman}

Correlated Random Effects - Hausman Test

Pool: ANGUIH

Test cross-section random effects

\begin{tabular}{|c|c|c|c|c|}
\hline Test Summary & & $\begin{array}{l}\text { Chi-Sq. } \\
\text { Statistic }\end{array}$ & Chi-Sq. d.f. & Prob. \\
\hline Cross-section random & & 54.752241 & 3 & 0.0000 \\
\hline \multicolumn{5}{|c|}{ Cross-section random effects test comparisons: } \\
\hline Variable & Fixed & Random & Var(Diff.) & Prob. \\
\hline CAR? & 0.022127 & 0.022766 & 0.000002 & 0.6043 \\
\hline NPF? & 0.058473 & 0.017701 & 0.000052 & 0.0000 \\
\hline BOPO? & -0.111584 & -0.105001 & 0.000003 & 0.0002 \\
\hline
\end{tabular}

Cross-section random effects test equation:

Dependent Variable: ROA?

Method: Panel Least Squares

Date: 08/19/16 Time: 14:36

Sample: 2009Q1 2015Q4

Included observations: 28

Cross-sections included: 5

Total pool (balanced) observations: 140

\begin{tabular}{lllll}
\hline \hline Variable & Coefficient & Std. Error & t-Statistic & Prob. \\
\hline \hline C & 10.63077 & 0.344181 & 30.88717 & 0.0000 \\
CAR? & 0.022127 & 0.007098 & 3.117426 & 0.0022 \\
NPF? & 0.058473 & 0.024455 & 2.391063 & 0.0182 \\
BOPO? & -0.111584 & 0.004125 & -27.05227 & 0.0000 \\
\hline \hline
\end{tabular}

Cross-section fixed (dummy variables)

\begin{tabular}{llll}
\hline \hline R-squared & 0.894296 & Mean dependent var & 1.192214 \\
Adjusted R-squared & 0.888691 & S.D. dependent var & 1.051214 \\
S.E. of regression & 0.350717 & Akaike info criterion & 0.797771 \\
Sum squared resid & 16.23632 & Schwarz criterion & 0.965865 \\
Log likelihood & -47.84396 & Hannan-Quinn criter. & 0.866079 \\
F-statistic & 159.5392 & Durbin-Watson stat & 0.627376
\end{tabular}




\section{Prob(F-statistic) $\quad 0.000000$}

Sumber: Data Diolah Penulis

Hasil output di atas menunjukkan nilai Prob $=0,0000$ yang berarti nilainya kurang dari 0,05. Sehingga dapat disimpulkan model Fixed Effect lebih tepat digunakan daripada model Random Effect.

Uji Hausman juga dapat dilakukan dengan membandingkan perhitungan $C h i$ Square $_{\text {statistik dengan Chi } \text { Square }_{\text {tabel. }} \text {. Dengan }}$ pengambilan keputusan sebagai berikut

a. Nilai Chi Square $_{\text {statistik }}>$ Chi Square $_{\text {tabel, }}$ maka $\mathrm{H}_{0}$ ditolak dan $\mathrm{H}_{\mathrm{a}}$ diterima. b. Nilai Chi Square $_{\text {statistik }}<$ Chi Square tabel, maka $\mathrm{H}_{0}$ diterima dan $\mathrm{H}_{\mathrm{a}}$ ditolak.

Diperoleh Chi Square $_{\text {statistik sebesar }}$ 54,752241 dengan Chi Square tabel 7.815 pada df (3) yang berarti Chi Square $_{\text {statistik }}>$ Chi Square tabel, maka $\mathrm{H}_{0}$ ditolak dan $\mathrm{H}_{\mathrm{a}}$ diterima. Sehingga dapat disimpulkan model Fixed Effect lebih tepat digunakan daripada model Random Effect.

\section{Uji Signifikansi}

Berdasarkan uji yang dilakukan yaitu uji Chow dan uji Hausman, model estimasi data yang terpilih adalah Model Fixed Effect. Maka selanjutnya dilakukan uji signifikansi dari model yang terpilih.

\section{Tabel VII}

Uji Signifikansi Fixed Effect

Dependent Variable: ROA?

Method: Pooled Least Squares

Date: 08/18/16 Time: 11:24

Sample: 2009Q1 2015Q4

Included observations: 28

Cross-sections included: 5

Total pool (balanced) observations: 140

\begin{tabular}{lllll}
\hline \hline Variable & Coefficient & Std. Error & t-Statistic & Prob. \\
\hline \hline C & 10.63077 & 0.344181 & 30.88717 & 0.0000 \\
CAR? & 0.022127 & 0.007098 & 3.117426 & 0.0022 \\
NPF? & 0.058473 & 0.024455 & 2.391063 & 0.0182 \\
BOPO? & -0.111584 & 0.004125 & -27.05227 & 0.0000 \\
Fixed Effects (Cross) & & & & \\
BMI-C & -0.083341 & & \\
BSM-C & -0.577930 & & \\
BMS-C & 0.615260 & & \\
BBS-C & -0.053933 & & \\
BRIS-C & 0.099944 & & \\
\hline \hline
\end{tabular}

Cross-section fixed (dummy variables)

\begin{tabular}{llll}
\hline \hline R-squared & 0.894296 & Mean dependent var & 1.192214 \\
Adjusted R-squared & 0.888691 & S.D. dependent var & 1.051214 \\
S.E. of regression & 0.350717 & Akaike info criterion & 0.797771 \\
Sum squared resid & 16.23632 & Schwarz criterion & 0.965865
\end{tabular}




\begin{tabular}{llll} 
Log likelihood & -47.84396 & Hannan-Quinn criter. & 0.866079 \\
F-statistic & 159.5392 & Durbin-Watson stat & 0.627376 \\
Prob(F-statistic) & 0.000000 & & \\
\hline
\end{tabular}

Sumber: Data Diolah Penulis

\section{Uji Pengaruh Parsial (Uji t)}

Uji $t$ digunakan untuk menguji adanya pengaruh terhadap variabel independen dengan variabel dependen secara individu dengan anggapan variabel lain bersifat konstan. Nilai thitung digunakan untuk menguji apakah variabel tersebut signifikan terhadap variabel tergantung atau tidak. Suatu variabel akan memiliki pengaruh yang berarti jika nilai $t_{\text {hitung }}>t_{\text {tabel }}$.

$$
\begin{aligned}
\mathrm{t}_{\text {tabel }}(\mathrm{t} \text { kritis }) & =|\alpha ; \mathrm{df}=(\mathrm{n}-\mathrm{k})| \\
& =5 \% ; \mathrm{df}=(140-4) \\
& =0,05 ; \mathrm{df}=(136) \\
& =1,978
\end{aligned}
$$

Berikut ini adalah uji $\mathrm{t}$ dari masingmasing variabel independennya terhadap variabel dependen:

a. Hubungan Linear Variabel Capital Adequacy Ratio (CAR) terhadap Return On Asset (ROA)

$\mathrm{H}_{0}: \mathrm{b}_{1}=0$, tidak terdapat pengaruh signifikan antara variabel Capital Adequacy Ratio (CAR) terhadap Return On Asset (ROA).

$\mathrm{H}_{\mathrm{a}}: \mathrm{b}_{1} \neq 0$, terdapat pengaruh signifikan antara variabel Capital Adequacy Ratio (CAR) terhadap Return On Asset (ROA).

Berdasarkan hasil uji t, untuk variabel Capital Adequacy Ratio (CAR) di dapat nilai sebesar 3,117426 yang berarti nilai $t_{\text {hitung }}(3,117426)>t_{\text {tabel }}$ (1,978), maka $\mathrm{H}_{0}$ ditolak dan $\mathrm{H}_{\mathrm{a}}$ diterima. Dapat disimpulkan bahwa variabel Capital Adequacy Ratio (CAR) secara parsial dan signifikan serta berpengaruh nyata terhadap Return On Asset (ROA).

b. Hubungan Linear Variabel Non Performing Financing (NPF) terhadap Return On Asset (ROA)

$\mathrm{H}_{0}: \mathrm{b}_{1}=0$, tidak terdapat pengaruh signifikan antara variabel Non
Performing Financing (NPF) terhadap Return On Asset (ROA).

$\mathrm{H}_{\mathrm{a}}: \mathrm{b}_{1} \neq 0$, terdapat pengaruh signifikan antara variabel Non Performing Financing (NPF) terhadap Return On Asset (ROA).

Berdasarkan hasil uji t, maka variabel Non Performing Financing (NPF) didapat nilai sebesar 2,391063 yang berarti nilai $t_{\text {hitung }}(2,931063)>t_{\text {tabel }}$ $(1,978)$, maka $\mathrm{H}_{0}$ ditolak dan $\mathrm{H}_{\mathrm{a}}$ diterima. Dapat disimpulkan bahwa variabel Non Performing Financing (NPF) secara parsial dan signifikan serta berpengaruh nyata terhadap Return On Asset (ROA).

c. Hubungan Linear Variabel Biaya Operasional Perpendapatan Operasional (BOPO) terhadap Return On Asset (ROA)

$\mathrm{H}_{0}: \mathrm{b}_{1}=0$, tidak terdapat pengaruh signifikan antara variabel Biaya Operasional Perpendapatan Operasional (BOPO) terhadap Return On Asset (ROA).

$\mathrm{H}_{\mathrm{a}}: \mathrm{b}_{1} \neq 0$, terdapat pengaruh signifikan antara variabel Biaya Operasional Perpendapatan Operasional (BOPO) terhadap Return On Asset (ROA).

Berdasarkan hasil uji t, maka variabel Biaya Operasional Perpendapatan Operasional (BOPO) didapat nilai sebesar $-27,05227$ yang berarti nilai thitung $(-27,05227)<t_{\text {tabel }}$ $(1,978)$, maka $\mathrm{H}_{0}$ diterima dan $\mathrm{H}_{\mathrm{a}}$ ditolak. Dapat disimpulkan bahwa variabel Biaya Operasional Perpendapatan Operasional (BOPO) secara parsial berpengaruh negatif signifikan dan tidak nyata terhadap Return On Asset (ROA).

Uji Pengaruh Simultan (Uji F) 
Dalam menyimpulkan apakah model masuk dalam kategori cocok (fit) atau tidak, kita harus membandingkan nilai $F_{\text {hitung }}$ dengan nilai $\mathrm{F}_{\text {tabel }}$ dengan derajat bebas : df $\alpha,(\mathrm{K}-1),(\mathrm{N}-\mathrm{K}) . \mathrm{K}$ disini adalah jumlah variabel independen dan dependen dan $\mathrm{N}$ adalah jumlah pengamatan (ukuran sampel). Pedoman yang digunakan dalam

(140-4) adalah 2,67 yang berarti nilai $F_{\text {hitung }}>\mathrm{F}_{\text {tabel. }}$. Maka $\mathrm{H}_{0}$ ditolak dan $\mathrm{H}_{\mathrm{a}}$ diterima. Hasil menunjukkan bahwa variabel independen (CAR, NPF dan BOPO) secara bersama-sama (simultan) berpengaruh positif terhadap variabel dependen (ROA).

\section{Uji Koefisien Determinasi $\left(\mathbf{R}^{\mathbf{2}}\right)$}

Dari tabel Fixed Effect di atas, menunjukkan nilai $R$ Square pada model regresi adalah 0,894296 yang menunjukkan kemampuan variabel independen (CAR, NPF dan BOPO) dalam menjelaskan variabel dependen adalah sebesar 89,4296\%, sedangkan sisanya sebesar $10,5704 \%$ di jelaskan variabel lain yang tidak termasuk dalam penelitian ini.

\section{Nilai Konstanta}

Nilai konstanta sebesar 10,63077 menunjukkan bahwa jika variabel independen yang terdiri dari Capital Adequacy Ratio (CAR), Non Performing Financing (NPF) dan Biaya Operasional Perpendapatan Operasional (BOPO) bernilai 0, maka nilai Dividend Payout Ratio adalah 10,63077 .

Berdasarkan penjelasan di atas, maka model persamaan Fixed Effect yang terbentuk adalah:

\section{$\mathrm{ROA}=10,63077+0,022127 * \mathrm{CAR}+\mathbf{0 , 0 5 8 4 7 3}$ *NPF-0,111584*BOPO}

\section{KESIMPULAN}

Berdasarkan data hasil penelitian, maka ditarik kesimpulan berdasarkan hasil analisis dan pembahasan yang dilakukan. Adapun kesimpulan meliputi:
1. Capital Adequacy Ratio (CAR) berpengaruh positif dan signifikan terhadap Return On Asset karena

pengambilan kesimpulan uji $\mathrm{F}$ adalah sebagai berikut:

1. Jika $F_{\text {hitung }}>F_{\text {tabel}}$, maka $\mathrm{H}_{0}$ ditolak dan $\mathrm{H}_{\mathrm{a}}$ diterima

2. Jika $F_{\text {hitung }}<\mathrm{F}_{\text {tabel}}$, maka $\mathrm{H}_{0}$ diterima dan $\mathrm{H}_{\mathrm{a}}$ ditolak

Dari hasil output dapat dilihat bahwa nilai $F_{\text {hitung }}$ adalah 159,5392 dengan $F_{\text {tabel }}$ dengan df: $\alpha,(\mathrm{K}-1),(\mathrm{N}-\mathrm{K})$ atau $0,05,(4-1)$, memiliki sig. $<0,05(0,0000<0,05)$ dan nilai $t_{\text {hitung }}>\mathrm{t}_{\text {tabel }}(3,117426>1,978)$.

2. Non Performing Financing (NPF) berpengaruh positif dan signifikan terhadap Return On Asset karena memiliki sig. $<0,05(0,0000<0,05)$ dan nilai $t_{\text {hitung }}>\mathrm{t}_{\text {tabel }}(2,931063>1,978)$.

3. Biaya Operasional Perpendapatan Operasional (BOPO) berpengaruh negatif dan signifikan terhadap Return On Asset karena memiliki sig. $<0,05(0,0000<$ $0,05)$ dan nilai $t_{\text {hitung }}<t_{\text {tabel }}(-27,05227<$ 1,978).

4. Secara simultan atau uji $\mathrm{F}$ ditemukan bahwa terdapat pengaruh yang signifikan pada variabel independen (CAR, NPF dan BOPO) terhadap ROA, karena memiliki nilai sig. $<0,05(0,0000<0,05)$ dan nilai $F_{\text {hitung }}>F_{\text {tabel }}(159,5392>2,67)$.

Saran penulis dalam penelitian ini adalah:

1. Dalam penelitian ini hanya rasio CAR, NPF dan BOPO yang menjadi variabel independennya. Jadi diharapkan untuk penelitian selanjutnya dapat menambah atau mengembangkan variabel selain variabel yang telah digunakan dalam penelitian ini seperti variabel Financing to Deposit Ratio (FDR).

2. Bagi Akademis diharapkan penelitian ini dapat dijadikan tambahan pengetahuan bagi penelitian selanjutnya. Untuk penelitian selanjutnya diharapkan menambahkan jumlah variabel dan periode penelitian contohnya melibatkan variabel Financing to Deposit Ratio (FDR), karena masih terdapat 10,5704\% variabel yang dapat mempengaruhi Return On Asset. 
3. Bagi Nasabah diharapkan dengan mengetahui apa saja yang dapat mempengaruhi ROA berarti mengetahui tingkat kesehetan suatu bank, maka bagi nasabah perlu menganalisa apa saja yang dapat mempengaruhi ROA sehingga nasabah dapat memperkirakan kapan berinvestasi dan kapan akan mulai menarik investasinya.

4. Bagi Bank diharapkan hasil penelitian ini dapat dijadikan informasi tambahan dan pertimbangan bagi Bank Muamalat Indonesia, Bank Syariah Mandiri, Bank Mega Syariah, Bank Bukopin Syariah dan Bank BRI Syariah dalam melakukan kebijakan yang berhubungan dengan investasi. Bagi bank-bank lebih mengawasi laporan keuangan lebih baik lagi sehingga investor dan nasabah akan percaya dan yakin dalam menanamkan modalnya pada bank tersebut.

\section{REFERENSI}

Adiwarman A. Karim, Analisis Fiqh dan Keuangan, Jakarta: PT. Raja Grafindo Persada, 2010.

Agus Widarjono, Ekonometrika Pengantar dan Aplikasinya: Disertai Panduan EViews, Yogyakarta: UPP STIM YKPN, 2013.

Amir Machmud dan Rukmana, Bank Syariah (Teori, Kebijakan, dan Studi Empiris di Indonesia), Jakarta: PT Gelora Aksara Pratama, 2009.

Arridho Yunanda, Pengaruh Capital Adequacy Ratio (CAR), Non Performing Financing (NPF), Kualitas Aktiva Produktif (KAP), Biaya Operasional Pendapatan Operasional (BOPO), Financing Deposit Ratio (FDR) Terhadap Profitabilitas Bank Umum Syariah yang terdaftar di Bank Indonesia, Skripsi, Pekanbaru: Perpustakaan UIN Suska Riau, 2013.
Dahlan Siamat, Manajemen Lembaga Keuangan, Jakarta: FEUI, 2007.

Daris Purba, Pengaruh Kecukupan Modal, Likuiditas, dan Efisiensi Operasional Terhadap Profitabilitas Pada PT Bank Muamalat Indonesia, Tbk., Skripsi UIN Syarif Hidayatullah, Jakarta. 2011.

Dedi Rosadi, Ekonometrika \& Analisis Runtun Waktu Terapan dengan EViews, Yogyakarta: ANDI OFFSET, 2012.

Etta Mamang Sangadji, Metodologi Penelitian, Yogyakarta: CV. Andi Offset, 2010.

Gujarati, N. Damodor dan Dawn C Porter, Dasar-Dasar Ekonometrika, Edisi Ke5, Salemba Empat, Jakarta, 2009.

Jonni J Manurung, dkk, Ekonometrika Teori dan Aplikasi, Jakarta: PT Elex Media Komputindo, 2010.

Lukman Dendawijaya, Manajemen Perbankan, Jakarta: Ghalia Indonesia, 2009, Cet. Ke-2.

Moch. Doddy Ariefianto, Ekonometrika Esensi dan Aplikasi dengan Menggunakan EViews, Jakarta: Erlangga, 2012.

Nadia Arini Haq, Pengaruh Pembiayaan dan Efisiensi Terhadap Profitabilitas Bank Umum Syariah, Jurnal Perbanas Review Volume 1 Fakultas Ekonomi dan Bisnis Perbanas Institute, 2015

Peraturan Bank Indonesia No. 15/12/PBI/2013 Tentang Kewajiban Penyediaan Modal Minimum Bank Umum.

Prapto Yuwono, Pengantar Ekonometri, Yogyakarta: ANDI OFFSET, 2005.

Ridhlo Ilham Putra Wardana, Analisis Pengaruh CAR, FDR, NPF, BOPO dan SIZE terhadap Profitabilitas Pada Bank Umum Syariah di Indonesia (Studi Kasus Pada Bank Umum Syariah di Indonesia Periode 2011- 
2014, Skripsi Universitas Diponegoro, Semarang, 2015.

Rizal Yaya, dkk, Akuntasi Perbankan Syariah, Jakarta: Salemba Empat, 2009.

Selamet Riyadi, Banking Assets and Liability Management, Jakarta: Fakultas Ekonomi Universitas Indonesia, 2006, Ed. Ke-3.

Suliyanto, Ekonometrika Terapan: Teori \& Aplikasi dengan SPSS, Yogyakarta: ANDI Yogyakarta, 2011.

Sumadi Suryabrata, Metodologi Penelitian, Jakarta: PT RajaGrafindo Persada, 2006.

Veithzal Rivai, dkk, Bank and Financial Institution Management (Conventional \& Sharia System), (Jakarta: PT. RajaGrafindo Persada, 2007. dan Arviyan Arifin, Islamic

Banking (Sistem Bank Islam Bukan Hanya Solusi Menghadapi Krisis Namun Solusi dalam Menghadapi Berbagai Persoalan Perbankan \& Ekonomi Global), Jakarta: Bumi Aksara, 2010, Cet. Ke-1.

Wahid Sulaiman, Analisis Regresi Menggunakan SPSS, Yokyakarta: Andi Offsed, 2014.

http://www.bankmuamalat.co.id/hubunganinvestor/laporan-triwulan

http://www.bi.go.id/id/Kamus.aspx?id=N

http://www.bi.go.id/id/publikasi/laporankeuangan/bank/umum konvensional/Default.aspx

http://www.brisyariah.co.id/?q=laporankeuangan

http://www.megasyariah.co.id/ http://www.ojk.go.id/id/kanal/perbankan/dat a-dan-statistik/laporan-keuanganperbankan/Default.aspx http://www.syariahbukopin.co.id/id/laporan http://www.syariahmandiri.co.id/category/in vestor-relation/ 